\title{
Enteric redmouth disease: outbreak in rainbow trout in Switzerland
}

\author{
W. Meier \\ Untersuchungsstelle für Fischkrankheiten, Vet. path. Inst. Universität Bern, Länggasstr. 122, CH-3012 Bern, Switzerland
}

ABSTRACT: Yersinia ruckeri, Serovar I or Hagerman strain, has been isolated from the first outbreak of enteric redmouth disease in Switzerland. The disease occurred in rainbow trout Salmo gairdneri Richardson. Relevant epizootiological data are discussed.

Since the first description of enteric redmouth disease (ERM) in rainbow trout Salmo gairdneri Richardson in the USA (Ross et al. 1966) the disease has been observed in trout in Canada (Wobeser 1973, McCarthy \& Johnson 1982) and in a number of European countries including Italy (Busch 1978), Great Britain (Roberts 1983, Frerichs et al. 1985), West Germany (Fuhrmann et al. 1983), France (Lesel et al. 1983), and Denmark (Dalsgaard et al. 1984). Recently, the agent has also been isolated in Eire from imported goldfish (McArdle \& Dooley-Martyn 1985).

Material and methods. In'a Swiss rainbow trout farm - in ponds supplied with spring water - the mortality of fish suddenly increased in July 1985 from less than $0.5 \%$ to more than $5 \%$ per week. The increase in mortality rate coincided with a rise of the water temperature from 10 to $12{ }^{\circ} \mathrm{C}$ and with the start of a partial recirculation of water within the fish farm. Initially, the mortalities occurred among 200000 fingerlings ( 8 to 12 $\mathrm{cm})$. However, 5 to $7 \mathrm{~d}$ later, older fish $(24$ to $30 \mathrm{~cm})$ were also affected although to a lower degree. The affected fish had been imported from a German hatchery 2 and 14 mo previously, respectively. Fingerlings on the present farm were again affected in June 1986.

Bacteriological examinations of the dying fish were performed using blood agar and bromthymol blue lactase agar; biochemical reactions were determined in standard tube tests according to Fey (1978). Rabbit anti Yersinia ruckeri serum, kindly donated by P.E.V. Jørgensen, Aarhus, Denmark, was used for the slide agglutination test.

Results. The major clinical signs were similar to those described for ERM (Ross et al. 1966, Lesel et al. 1983, Fuhrmann et al. 1983) and included hyperaemia around the mouth and in the isthmus. While virological and parasitological examinations of moribund fish gave no clues as to the cause of the mortalities, bacteriological examination yielded pure cultures of a bacterium from kidney, liver and spleen tissues. The bacterium grew readily (in 2 d) at $25^{\circ} \mathrm{C}$ on the agars used, but not at $37^{\circ} \mathrm{C}$. The bacterium was a Gramnegative, motile rod $(0.7$ to $1.0 \mu \mathrm{m} \times 2.0$ to $3.0 \mu \mathrm{m})$; it was catalase positive and oxidase negative. After $4 \mathrm{~d}$ at $25^{\circ} \mathrm{C}$, the following tests of the fermentative bacterium were negative: Voges Proskauer, sorbitol, gas from glucose, indole, urease, lysine, malonate, dulcitol, adonitol, $\mathrm{H}_{2} \mathrm{~S}$-production, salicin, sucrose, rhamnose, inositol, d-tartrate and sodium citrate. The following tests were positive: mannitol, $\mathrm{KCN}$, ornithine, galactosidase, nitrate, and gelatin liquefaction. Finally, Simmons citrate and ONPG were weakly positive. In tests run in parallel, the isolate proved identical to Yersinia ruckeri reference strain NCMB 1316 (National Collection of Marine and Industrial Bacteria Ltd., USA). However, because of the negative reaction in the Voges Proskauer test, the present strain was different from the isolates from Britain (Frerichs et al. 1985) and Germany (Fuhrmann et al. 1983). A positive agglutination with a rabbit anti $Y$. ruckeri serum prepared against the Serovar I or Hagerman strain further supported the identification of the isolate as Y. ruckeri, serovar I.

Discussion. This isolation of Yersinia ruckeri clearly demonstrates the occurrence of ERM in Switzerland. However, the source of the pathogen is still uncertain. It is generally agreed that ERM may become established in new areas following its introduction with carrier-fish (Rucker 1966, Wobeser 1973, Busch \& Lingg 1975). However, there is also evidence that $Y$. ruckerf is widely distributed and that fish-mediated transmission may not always account for its distribution (Bullock et al. 1978).

The German hatchery serving as the source of the 
rainbow trout has been regularly examined by the local German Fish Health Service. However, to date, the causative agent of ERM has not been detected at the hatchery. The same trout farm also supplies 2 other Swiss farms. The latter have been routinely examined since 1981 but so far, no ERM has been detected in either of them. Notwithstanding this, because the frequency of ERM carrier-fish is generally rather low (Busch \& Lingg 1975) one cannot exclude the possibility that the infection was introduced into the affected farm by carriers from the German farm.

The Yersinia ruckeri affected farm, established 5 yr ago, uses only spring water and therefore carrier fish do not occur in its water supply. Until the ERM disease outbreaks, the farm had been regularly surveyed but signs of ERM disease had never been evident and it had never been possible to isolate $Y$. ruckeri. Environmental factors probably precipitated the ERM disease outbreak. These factors likely included the rising water temperature and a decreasing water quality as caused by the partial water recirculation and the high stocking density at the hatchery.

At present, ERM appears not to be enzootic in Switzerland. Among the more than 1500 trout and other feral fish recently tested bacteriologically in Switzerland, the only case of ERM found was the alreadymentioned ERM relapse that occurred at the affected trout farm (June 1986). Unfortunately, the foregoing situation may soon change. Trout, pike, grayling, and ornamental fish are all potential carriers of ERM (Roberts 1983, McArdle \& Dooley-Martyn 1985), and these fish are constantly imported into Switzerland for consumption and restocking purposes. In addition, fish farming is growing in popularity in Switzerland and heightened activity in this sphere will almost certainly increase the likelihood that the disease will be imported.

\section{LITERATURE CITED}

Bullock, G. L., Stuckey, H. M., Shotts, E. B., Jr. (1978). Enteric redmouth bacterium: comparison of isolates from different geographic areas. J. Fish Dis. 1: 351-356

Busch, R. A. (1978). Enteric redmouth disease (Hagerman strain). Mar. Fish. Rev. 40 (3): 42-51

Busch, R. A., Lingg, A. (1975). Establishment of an asymptomatic carrier state infection of enteric redmouth disease in rainbow trout. J. Fish. Res. Bd Can. 32: 2429-2432

Dalsgaard, I., From, J., Hørlyck, V. (1984). First observation of Yersinia ruckeri in Denmark. Bull. Eur. Ass. Fish Pathol. 4: 10

Fey, H. (1978). Kompendium der allgemeinen medizinischen Bakteriologie. Verlag Paul Parey, Berlin, Hamburg

Frerichs, G. N., Stewart, J. A., Collins, R. O. (1985). Atypical infection of rainbow trout, Salmo gairdnen Richardson, with Yersinia ruckeri. J. Fish Dis. 8: 383-387

Fuhrmann, H., Bohm, K. H., Schlotfeldt, H. J. (1983). An outbreak of enteric redmouth disease in West Germany. J. Fish Dis. 6: 309-311

Lesel, R., Lesel, M., Gavini, F., Vuillaume, A. (1983). Outbreak of enteric redmouth disease in rainbow trout, Salmo gairdneri Richardson, in France. J. Fish Dis. 6: 385-387

McArdle, J. F., Dooley-Martyn, C. (1985). Isolation of Yersinia rucken Type I (Hagerman strain) from goldfish, Carassius auratus, Bull. Eur. Ass. Fish Pathol. 5: 10-11

McCarthy, D. H., Johnson, K. A. (1982). A serotypic survey and crossprotection test of North American field isolates of Yersinia ruckeri. J. Fish Dis. 5: 323-328

Roberts, M. S. (1983). A report of an epizootic in hatcheryreared rainbow trout, Salmo gairdneri Richardson, at an English trout farm, caused by Yersinia ruckeri. J. Fish Dis. 6: 551-552

Ross, A. J., Rucker, R. R., Ewing, W. H. (1966). Description of a bacterium associated with redmouth disease of rainbow trout (Salmo gairdneri). Can. J. Microbiol. 12: 763-770

Rucker, R. R. (1966). Redmouth disease of rainbow trout (Salmo gairdneri). Bull. Off. Int. des Epiz. 65: 825-830

Wobeser, G. (1973). An outbreak of redmouth in rainbow trout (Salmo gairdneri) in Saskatchewan. J. Fish. Res. Bd Can. 30: $571-575$

Responsible Subject Editor: Dr. T. Evelyn; accepted for printing on December 5, 1986 